\title{
DIVERSITY AND ABUNDANCE OF GASTROPODS IN KAWAL AND PENGUDANG BEACH, BINTAN REGENCY
}

\author{
Nisha Desfi Arianti $^{1}$ - Mey Krisselni Sitompul ${ }^{1}$
}

Ringkasan Kawal Beach and Pengudang Beach are sandy beaches located in Bintan Regency, Kepualauan Riau Province. The two beaches have almost similar activities, is there are fishermen settlements. The difference is that $\mathrm{Ka}$ wal Beach is located around beach tourism activities, while Pengudang Beach has no beach tourism activities. The purpose of this study was to understand how diversity and abundance gastropods in Kawal and Pengudang beach, then the similarity-based Bray-Curtis similarity in both locations. The method of determining the research location at Kawal Beach and Pengudang Beach is purposive sampling. The gastropod samples were collecting use transect with a quadrat of $1 \mathrm{~m} 2$ at the lowest tide zone along 100 meters towa$r d$ the sea. They were taken by hand then put into a labeled zip lock plastic. Samples were then identified, documented and their diversity and abundance were calculated. A total of 42 species of gastropods were identified belonging to 15 families with an abundance index $3433 \mathrm{ind} / \mathrm{m} 2$ for Kawal Be-

\footnotetext{
1) Universitas Karimun Jl. Canggai Putri, Kecamatan Tebing, Kabupaten Karimun

E-mail: nishadesfiarianti@gmail.com
}

ach and 1564 ind/m2 for Pengudang Beach. Diversity of gastropods species are $\left(H^{\prime}\right)$ 1,83; (E) 0,5; and $(C) 0,3$ for Kawal Beach, (H') 2,55; (E) 0,7; and (C) 0,1 for Pengudang Beach. BrayCurtis similarity shown is $P K 1-P P 1=0,33$; $P K 2-P P 2=0,34$; and $P K 3-P P 3=0,15$. This study is important in providing information on gastropods that live in the Kawal dan Pengudang beach. For future research should focus on temporal research in more depth to provide knowledge of gastropods communities and their ecological importance.

Keywords abundance, Bintan island, diversity, dominance,

\section{PENDAHULUAN}

Pantai Kawal dan Pengudang adalah pantai berpasir yang terletak di Kabupaten Bintan, Provinsi Kepulauan Riau. Kedua pantai tersebut dipengaruhi oleh pasang surut air laut. Pada saat air surut, dasar pantai bisa menjadi sangat kering. Tarikan gravitasi bulan dan matahari menyebabkan pasang naik dan turun setiap 6 jam di sebagian besar wilayah pesisir. Organisme yang hidup 
di zona ini harus mampu menghindari tersapu oleh gelombang dan harus menghadapi tenggelam saat air pasang. Mereka juga harus bertahan hidup dari perubahan tingkat salinitas saat hujan. Untuk mengatasi tekanan gelombang, sebagian besar organisme intertidal berpegangan pada sesuatu (bebatuan), membenamkan diri, atau bersembunyi di cangkang pelindung.

Pantai Kawal memiliki aktivitas wisata dan Pantai Pengudang memiliki aktivitas lokal seperti mengumpulkan moluska. Pantai Kawal berada di sekitar kawasan wisata dan Pantai Pengudang merupakan kawasan nelayan pengumpul moluska. Asumsi bahwa aktivitas di sekitar pantai sedikit banyak akan mempengaruhi komponen-komponen yang ada di perairan tersebut. Perubahan salah satu komponen di perairan akan berpengaruh terhadap keanekaragaman dan kelimpahan biota di dalamnya. Perubahan struktur Gastropoda dapat berupa keanekaragaman, kelimpahan, dll. Penilaian kualitas air dapat dilakukan dengan 3 (tiga) cara yaitu analisis fisik, analisis kimiawi, dan analisis biologi. Analisis biologi yang biasa digunakan untuk memberikan gambaran kondisi perairan adalah melihat struktur komunitas bentik. Salah satu komunitas hewan bentik yang dapat digunakan sebagai bioindikator di dalam air adalah Gastropoda. Gastropoda merupakan salah satu moluska yang menyusun komunitas bentik di perairan yang bergerak menggunakan otot perut, mengalami torsi dan sistem cangkang, bentuk cangkangnya kerucut bengkok. Badan gastropoda sangat bervariasi dalam bentuk dan ukurannya. Gastropoda memiliki cangkang berulir tunggal, kepala berkembang dengan baik, dilengkapi dengan tentakel dan mata.

Gastropoda sensitif terhadap perubahan lingkungan dan dikategorikan sebagai kelompok organisme fakultatif yang dapat bertahan hidup dalam perubahan lingkungan yang sederhana. Kelimpahan dan keanekaragaman gastropoda laut dipengaruhi oleh faktor biotik dan abiotik seperti kondisi lingkungan, ketersediaan pangan, predasi predator, dan pemukiman. Menurut penelitian sebelumnya, derajat paparan aksi gelombang (Crowe et al., 2000; McQuaid and Lindsay, 2000; Zamprogno et al., 2012), variasi suhu (Harley et al., 2006), topografi pesisir (Crowe et al., 2000; Sorensen, 2012), kandungan organik dalam sedimen (Arruda and Amaral, 2003; Snelgrove and Butman, 1995), predasi (Moerland et al., 2016; Morton and Blackmore, 2009) dan gangguan manusia (Deepananda and Macusi, 2013) merupakan beberapa parameter yang mempengaruhi distribusi organisme pantai berbatu. Nassarius pullus dan Anadara uropigimelana merupakan sebagian spesies yang memiliki distribusi yang luas yang berpotensi di jadikan indikator biologis dalam penelitian mengenai adaptasi dan mitigasi perubahan iklim secara mendalam.

Beberapa kasus pemanenan gastropoda untuk dikonsumsi banyak terjadi di beberapa daerah seperti di Pantai Nasese Kepulauan Fuji (Suratissa and Rathnayake, 2017) hal ini memungkinkan akan menimbulkan bahaya jika aktivitas ini terus menerus dilakukan tanpa adanya kebijakan yang mengatur. Peraturan pemanenan pada ukuran tertentu terhadap kerang dan gastropoda yang akan melakukan pembenihan sangat diperlukan untuk keberlanjutan stok pe- 
manenan. Filipina dianggap sebagai Negara yang sangat beragam dalam hal moluska, akan tetapi penelitian tentang keanekaragaman moluska di Pulau Mindanao masih sangat sedikit (Jumawan et al., 2015).

Hal lain yang mempengaruhi keanekaragaman hayati adalah pencemaran minyak dari buangan kapal dapat mengancam moluska dan fauna lainnya. Pembuangan limbah (minyak) secara terus menerus dapat mempengaruhi keanekaragaman hayati, mempengaruhi kesehatan penduduk, dan berpotensi untuk ekowisata (Dolorosa and DanganGalon, 2014). Hal ini dapat mengindikasikan status pencemaran habitat. Di sisi lain, gastopoda memang model yang baik untuk menemukan pencemaran yang terjadi di laut karena variasi pencemaran akan tercermin pada bentuk cangkang (Primost et al., 2015).

Pantai Kawal merupakan pantai berbatu. Pantai berbatu dikatakan salah satu kawasan yang berbahaya dan rumit di antara ekosistem laut di dunia. Pertama, area ini terpapar udara langsung pada saat surut, sehingga berdampak pada faktor lingkungan lainnya seperti suhu salinitas, $\mathrm{pH}$ dan kandungan oksigen. Selain itu juga, organisme di pantai berbatu ini akan mendapatkan pengaruh dari angina kencang dan deburan ombak, serta efek pengeringan yang diakibatkan paparan sinar matahari (Alyakrinskaya, 2004; Sorensen, 2012), angin dan tingginya salinitas serta adanya organisme darat yang bersifat predator, hanyalah faktor kondisi lingkungan pendukung yang tidak dapat diprediksi pada lingkungan ini (Smith, 2013). Terlepas dari kondisi yang ekstrem tersebut, pantai berbatu selalu dipenuhi dengan hewan invertebrata karena mam- pu memberikan tempat berlindung (celah bebatuan / dibawah bebatuan).

Namun meskipun semua penelitian tersebut difokuskan pada keanekaragman gastropoda, tetap menjadi tantangan utama untuk dikaji. Karena perubahan iklim terus terjadi di bumi dan masing-masing daerah memiliki karakteristik yang berbedabeda sesuai dengan aktivitas yang terdapat dilokasi penelitian. Saat ini penulis tertarik menlakukan kajian atau penelitian di Pantai Kawal dan Pantai Pengudang. Karena secara lokasi, pantai ini sama-sama berada di Kabupaten Bintan, tetapi memiliki karakteristik yang berbeda. Penulis melakukan kajian mengenai keanekaragaman dan kelimpahan pada kedua pantai tersebut dengan harapan dapat menjadi informasi dalam menentukan kebijakan pelestarian lingkungan di kedua lokasi.

\section{MATERI DAN METODE}

Penelitian ini dilakukan pada tanggal 20 Juli hingga 20 Agustus 2020 pada dua pantai di Kabupaten Bintan yaitu pantai Kawal, dan pantai Pengudang (Gambar 1). Masing-masing lokasi terdiri dari 3 (tiga) stasiun dimulai dari bibir pantai kearah laut. Parameter fisik dan kimia perairan yang diukur meliputi suhu, $\mathrm{pH}$, oksigen terlarut (DO), dan salinitas. Pengukuran parameter suhu, $\mathrm{pH}$, oksigen terlarut menggunakan multimeter (Lovibond Senso Direct), salinitas menggunakan Handrefraktometer (Atago).

Pengambilan sampel gastropoda menggunakan transek dengan ukuran kuadrat $1 \mathrm{~m}^{2}$, sampel kemudian dimasukkan ke dalam plastik ziplock yang telah diberi label. Sampel gastropoda ditempatkan di kotak pendingin sebelum 


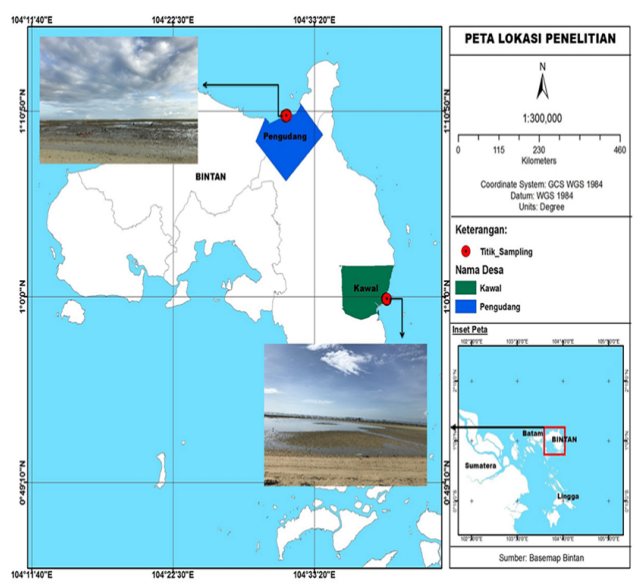

Gambar 1 Peta Lokasi Penelitian, Pantai Kawal dan Pantai Pengudang Kabupaten Bintan

dikeluarkan untuk identifikasi. Selanjutnya, sampel gastropoda diidentifikasi berdasarkan morfologi menggunakan WoRMS (World Register of Marine Species); www. marinespecies. org, dan https:// singapore. biodiversity. online.

$K=\frac{N_{i}}{A}$

Kelimpahan spesies (K) (ind $\left./ \mathrm{m}^{2}\right) ; \mathrm{N}_{i}$ : adalah jumlah individu suatu spesies (ind); dan A: adalah plot luas per meter persegi $\left(\mathrm{m}^{2}\right)$.

$H=\sum_{i=1}^{s} \frac{n_{i}}{N} \ln \frac{n_{i}}{N}$

$E=\frac{H^{\prime}}{H_{m a k s}}$

$D=\sum_{i=1}^{s} P_{i}^{2}$

Keanekaragaman jenis gastropoda diukur menggunakan indeks Shannon Wiener ( $\left.\mathrm{H}^{\prime}\right)$, keanekaragaman $\left(\mathrm{H}^{\prime}\right)$, indeks kemerataan (E), dan indeks dominansi (D).

dimana, H' = indeks keanekaragaman; $\mathrm{N}=$ jumlah total individu yang diama$\mathrm{ti} ; \mathrm{ni}=$ jumlah $\mathrm{i}$ individu; $\mathrm{Pi}=\mathrm{n} . \mathrm{N}^{-1}$; $\mathrm{Hmax}=\log _{2} \mathrm{~S}$
Indeks kemiripan spesies Gastropoda diukur menggunakan Bray-Curtis yang menstandarkan metrik Manhattan sehingga memiliki range dari 0 (similar) hingga 1 (dissimilar)

$B C=100\left(1-\frac{\sum_{i=1}^{n} \mid Y_{i j}-Y_{i k}}{\sum_{i=1}^{n}\left(Y_{i j}-Y_{i k}\right)}\right)$

dimana, $\mathrm{B}=$ ukuran ketidaksamaan BrayCurtis; $\mathrm{Y}_{i j}-\mathrm{Y}_{i k}=$ Jumlah individu dalam spesies i di setiap sampel $(\mathrm{j}, \mathrm{k}) ; \mathrm{n}=$ jumlah spesies dalam sampel

\section{HASIL DAN PEMBAHASAN}

Pantai Kawal memiliki karakteristik berpasir dan berbatu sedangkan Pantai Pengudang memiliki karakteristik berpasir dan ditumbuhi lamun. Desa Pengudang terdapat banyak lamun dan merupakan salah satu dari empat kawasan lindung padang lamun yang ada di Kabupaten Bintan. Pantai Kawal didominasi oleh aktivitas wisata dan memancing, sedangkan Pantai Pengudang didominasi oleh aktivitas pemanenan moluska oleh masyarakat setempat. Kondisi fisik dan kimiawi perairan yang ditunjukkan pada Tabel 1. menunjukkan bahwa baik suhu, salinitas, $\mathrm{pH}$ tidak berada dalam kisaran baku mutu yang ditetapkan oleh Kementerian Lingkungan Hidup Republik Indonesia No. 51 (2004). Nilai suhu di Pantai Desa Kawal lebih tinggi dari Pantai Desa Pengudang yaitu masing-masing $27,9^{\circ} \mathrm{C}$ dan $26,35^{\circ} \mathrm{C}$. Suhu ini lebih rendah dari nilai baku mutu, kemungkinan disebabkan karena pengambilan sampel dominan dilakukan setelah turun hujan. Selain itu, pengambilan dilakukan pada saat pagi hari, mengikuti waktu surut di lokasi pengambilan sampel. 
Tabel 1 Parameter fisika dan kimia di Pantai Kawal dan Pengudang

\begin{tabular}{|c|c|c|c|c|c|}
\hline \multirow{2}{*}{ Parameter } & \multicolumn{2}{|c|}{ Nilai Rata-Rata } & \multirow{2}{*}{ Nilai } & \multirow{2}{*}{ Alat } & \multirow{2}{*}{ Baku Mutu } \\
\hline & PK & PP & & & \\
\hline Temperature & 27,9 & 26,35 & ${ }^{\circ} \mathrm{C}$ & Multimeter & $28-30$ \\
\hline Salinity & 20 & 30 & $\%$ & Handrefraktometer & 33-34 \\
\hline $\mathrm{pH}$ & 6,09 & 5,38 & - & Multimeter & $7-8,5$ \\
\hline Dissolved Oxygen (DO) & 7,95 & 7,3 & $\mathrm{mg} / \mathrm{L}$ & Multimeter & $>5$ \\
\hline
\end{tabular}

Nilai salinitas di Pantai Kawal lebih rendah dari Pantai Pengudang, masing-masing adalah 20\%o, dan 30\%o. Nilai salinitas di Pantai Pengudang ini sama dengan nilai salinitas di Desa Olimoo'o yaitu 30\%o (Laxmana et al., 2020). Kedua pantai ini merupakan pantai dengan hamparan padang lamun. Selanjutnya nilai pH di Pantai Kawal lebih tinggi dari Pantai Pengudang masing-masing 6,09 dan 5,38. (Rumahlatu and Leiwakabessy, 2017 menjelaskan bahwa pH merupakan faktor lingkungan yang mempengaruhi penyebaran gastropoda. Semakin tinggi $\mathrm{pH}$, semakin tinggi keanekaragamannya. Namun pada penelitian ini nilai $\mathrm{pH}$ yang rendah di Pantai Pengudang tidak juga menunjukkan nilai keanekaragaman yang rendah, melainkan dalam kategori sedang. Sedangkan dengan nilai $\mathrm{pH}$ yang tinggi di Pantai Kawal, Indeks keanekaragaman termasuk dalam kategori kecil. Faktor lain yang mendukung kehidupan gastropoda adalah Dissolved Oxygen (DO). Nilai DO di Pantai Kawal dan Pantai Pengudang adalah $7,95 \mathrm{mg} / \mathrm{L}$ dan 7,3 $\mathrm{mg} / \mathrm{L}$. Nilai tersebut sesuai dengan nilai ketetapan baku matu yaitu $>5$. (Ekau et al., 2010) menjelaskan bahwa oksigen merupakan salah satu elemen penting dalam metabolisme organisme air.

Total gastropoda yang ditemukan di Pantai Kawal dan Pantai Pengudang adalah 42 spesies yang termasuk dalam 15 famili dengan nilai kelimpahan 3433 ind $/ \mathrm{m}^{2}$ untuk Pantai Kawal dan 1564 ind $/ \mathrm{m}^{2}$ untuk Pantai Pengudang. Terdapat 23 spesies gastropoda yang ditemukan di Pantai Kawal, terdiri dari 9 famili yaitu Batillariidae, Cerithiidae, Columbellidae, Costellariidae, Littorinidae, Muricidae, Nassariidae, Neritidae, dan Potamididae. Sedangkan gastropoda yang ditemukan di Pantai Pengudang berjumlah 35 spesies yang terdiri dari 14 famili yaitu Batillariidae, Cerithiidae, Columbellidae, Costellariidae, Cypraeidae, Melongednidae, Mitridae, Muricidae, Nacitidae, Nassariidae, Neritidae, Potamididae, Pyramidellidae dan Strombidae. Jumlah total spesies yang ditemukan di Pantai Kawal lebih banyak dari jumlah total spesies yang ditemukan di Pantai Pengudang, namun jika dilihat berdasarkan famili dapat dikatakan bahwa Pantai Pengudang lebih banyak daripada Pantai Kawal. Jenis yang ditemukan di kedua pantai tersebut dapat dilihat pada Tabel 2.

Hasil analisis kepadatan populasi spesies asli di setiap stasiun selama periode penelitian, memperlihatkan besaran kepadatan yang sangat rendah (1.33 $\left.\mathrm{Ind} / \mathrm{m}^{2}-4,66 \mathrm{Ind} / \mathrm{m}^{2}\right)$, meskiput tren nilai kepadatan pada setiap periode penelitian mengalami peningkatan. Kenaikan besaran nilai kepadatan populasi spesies asli (T. scabra dan N. pullige$r a)$ juga terlihat rendah. Berikut adalah grafik kepadatan populasi spesies asli (T. scabra dan N. pulligera) di perairan sungai Wandoke, Desa Gunung Sejuk Kabupaten Buton selatan.

Berdasarkan Tabel 2. terlihat bahwa $B a$ tillaria zonalis merupakan spesies yang terdapat di Pantai Kawal dan Pantai Pengudang dengan kelimpahan total tertinggi masing-masing $1403 \mathrm{ind} / \mathrm{m}^{2}$ dan $273 \mathrm{ind} / \mathrm{m}^{2}$. Hal serupa juga terjadi di 
Tabel 2 Kelimpahan gastropoda di Pantai Kawal dan Pengudang

\begin{tabular}{|c|c|c|c|c|c|c|c|c|c|}
\hline \multirow{3}{*}{ No } & \multirow{3}{*}{ Species } & \multicolumn{6}{|c|}{ Lokasi } & \multicolumn{2}{|c|}{ Total (ind/m2) } \\
\hline & & \multicolumn{3}{|c|}{ Kawal Beach (PK) } & \multicolumn{3}{|c|}{ Pengudang Beach (PP) } & \multirow{2}{*}{ PK } & \multirow{2}{*}{ PL } \\
\hline & & PK1 & PK2 & PK3 & PP1 & PP2 & PP3 & & \\
\hline 1 & Batillaria zonalis & 615 & 533 & 255 & 159 & 113 & 1 & 1403 & 273 \\
\hline 2 & Canarium urceus & 0 & 0 & 0 & 0 & 0 & 4 & 0 & 4 \\
\hline 3 & Cerithidae $s p$ & 3 & 0 & 0 & 14 & 5 & 0 & 3 & 19 \\
\hline 4 & Pirenella cingulata & 211 & 14 & 70 & 46 & 3 & 0 & 295 & 49 \\
\hline 5 & Cerithium litteratum & 0 & 0 & 0 & 0 & 31 & 2 & 0 & 33 \\
\hline 6 & Cerithium nodulosum & 0 & 0 & 0 & 0 & 0 & 1 & 0 & 1 \\
\hline 7 & Cerithium traillii & 122 & 0 & 331 & 0 & 11 & 1 & 453 & 12 \\
\hline 8 & Cerithium zebrum & 1 & 4 & 0 & 0 & 6 & 1 & 5 & 7 \\
\hline 9 & Clithon oualaniense & 3 & 2 & 7 & 20 & 57 & 21 & 12 & 98 \\
\hline 10 & Clypeomorus batillaformes & 0 & 21 & 61 & 0 & 0 & 2 & 82 & 2 \\
\hline 11 & Clypeomorus bifasciata & 0 & 15 & 50 & 0 & 0 & 0 & 65 & 0 \\
\hline 12 & Clypeomorus concisus & 26 & 5 & 60 & 14 & 0 & 0 & 91 & 14 \\
\hline 13 & Clypeomorus nympha & 2 & 0 & 0 & 0 & 0 & 0 & 2 & 0 \\
\hline 14 & Erronea errones & 0 & 0 & 0 & 1 & 0 & 0 & 0 & 1 \\
\hline 15 & Euplica scripta & 0 & 0 & 0 & 3 & 3 & 29 & 0 & 35 \\
\hline 16 & Indothais rufotincta & 0 & 0 & 0 & 0 & 0 & 1 & 0 & 1 \\
\hline 17 & Laevistrombus turturella & 0 & 0 & 0 & 3 & 39 & 55 & 0 & 97 \\
\hline 18 & Littoraria scabra & 0 & 0 & 1 & 0 & 0 & 0 & 1 & 0 \\
\hline 19 & Morulla striata & 1 & 6 & 2 & 0 & 0 & 0 & 9 & 0 \\
\hline 20 & Nassarius bellulus & 0 & 0 & 0 & 4 & 0 & 0 & 0 & 4 \\
\hline 21 & Nassarius bimaculossus & 0 & 0 & 0 & 25 & 0 & 6 & 0 & 31 \\
\hline 22 & Nassarius livescens & 0 & 0 & 0 & 0 & 1 & 0 & 0 & 1 \\
\hline 23 & Nassarius olivaceus & 0 & 0 & 0 & 1 & 0 & 0 & 0 & 1 \\
\hline 24 & Nassarius reticulatus & 0 & 0 & 0 & 1 & 2 & 0 & 0 & 3 \\
\hline 25 & Nassarius siquijorensis & 0 & 1 & 0 & 0 & 0 & 0 & 1 & 0 \\
\hline 26 & Nerita articulata & 8 & 16 & 1 & 0 & 0 & 0 & 25 & 0 \\
\hline 27 & Nerita undulata & 2 & 11 & 0 & 0 & 0 & 0 & 13 & 0 \\
\hline 28 & Neverita didyma & 0 & 0 & 0 & 1 & 0 & 0 & 0 & 1 \\
\hline 29 & Otopleura auriscati & 0 & 0 & 0 & 0 & 1 & 4 & 0 & 5 \\
\hline 30 & Pictocolumbella ocellata & 12 & 36 & 11 & 12 & 4 & 2 & 59 & 18 \\
\hline 31 & Pirenella incisa & 0 & 0 & 0 & 15 & 23 & 34 & 0 & 72 \\
\hline 32 & Pirenella retifera & 12 & 16 & 17 & 19 & 4 & 7 & 45 & 30 \\
\hline 33 & Pterygia undulosa & 0 & 0 & 0 & 0 & 2 & 0 & 0 & 2 \\
\hline 34 & Volegalea cochlidium & 0 & 0 & 0 & 2 & 7 & 4 & 0 & 13 \\
\hline 35 & Pusia ebenus & 1 & 0 & 1 & 51 & 4 & 7 & 2 & 62 \\
\hline 36 & Pyrene epamella & 0 & 11 & 0 & 0 & 4 & 0 & 11 & 4 \\
\hline 37 & Reishia bitubercularis & 0 & 2 & 0 & 0 & 0 & 0 & 2 & 0 \\
\hline 38 & Rhinoclavis vertagus & 0 & 0 & 0 & 0 & 0 & 18 & 0 & 18 \\
\hline 39 & Rhinoclavis sinensis & 0 & 0 & 0 & 1 & 0 & 0 & 0 & 1 \\
\hline 40 & Semiricinula fusca & 9 & 24 & 16 & 6 & 33 & 13 & 49 & 52 \\
\hline 41 & Terebralia palustris & 30 & 4 & 17 & 11 & 0 & 1 & 51 & 12 \\
\hline \multirow[t]{2}{*}{42} & Terebralia sulcata & 29 & 80 & 268 & 215 & 30 & 49 & 377 & 294 \\
\hline & Jumlah Total & 1116 & 881 & 1436 & 839 & 413 & 312 & 3433 & 1564 \\
\hline
\end{tabular}

Jepang, gastropoda dari genus Batillaria merupakan kelompok dominan di dataran yang mendapat pengaruh pasang surut, hal ini dikarenakan kebiasaan makan dari genus Batillaria ini adalah pemakan diatom bentik (Kamimura and Tsuchiya, 2004, Kamimura and Tsuchiya, 2006). Selain Batillaria zonalis, Terebralia sulcata juga meru- pakan spesies dengan jumlah tinggi di Pantai Kawal dan Pantai Pengudang. Hal ini diduga karena karakteristik dari lokasi penelitian sangat mendukung untuk kehidupan spesies tersebut. Selain itu, ada juga dari famili Muricidae yang dikenal sebagai siput batu. Siput batu ini merupakan siput yang menghuni habitat pesisir dan laut dalam jum- 
lah banyak (Mills et al., 2007). Selama penelitian, ditemukan siput jenis $\mathrm{Mo}$ rulla striata, Reishia bitubercularis, dan jenis Semiricinula fusca mendiami kedua pantai, dengan jumlah tertinggi yaitu Semiricinula fusca. Hal ini diduga karena spesies ini hidup menempel pada bebatuan. Sehingga sangat mudah ditemukan terutama pada saat air surut. Menurut (Zhang et al., 2016), kebiasaan menempel pada bebatuan yang dilakukan siput yaitu bertujuan untuk melindungi sistem dalam tubuhnya seperti sistem respirasi, ekskresi, pencernaan serta membantu gastropoda untuk bertahan hidup dan tumbuh kembang dalam ekosistem yang ekstrem.

Nilai indeks keanekaragaman, keseragaman, dan dominasi dapat dilihat pada Gambar 2. Nilai keanekaragaman di Pantai Kawal dan Pengudang masingmasing adalah 1,839 dan 2,550; nilai keseragaman di pantai Kawal dan Pengudang masing-masing adalah 0,5 dan 0,7; dan nilai dominasi di Pantai Kawal dan Pengudang masing-masing adalah 0,3 dan 0,1 . Hal ini menjelaskan bahwa keanekaragaman di Pantai Kawal termasuk dalam kategori kecil dan keanekaragaman di Pantai Pengudang termasuk dalam kategori sedang. Nilai keseragaman di Pantai Kawal dan Pantai Pengudang masuk dalam kategori komunitas dalam kondisi labil. Artinya, adanya variasi yang cukup besar pada komunitas tersebut. Nilai dominasi di Pantai Kawal dan Pantai Pengudang termasuk dalam kategori rendah.

Rendahnya indeks keanekaragaman gastropoda di kedua pantai tersebut diduga karena aktivitas masyarakat setempat seperti wisata, pembuangan sampah rumah tangga, dan penangkapan biota. Hal ini sesuai dengan pernyataan

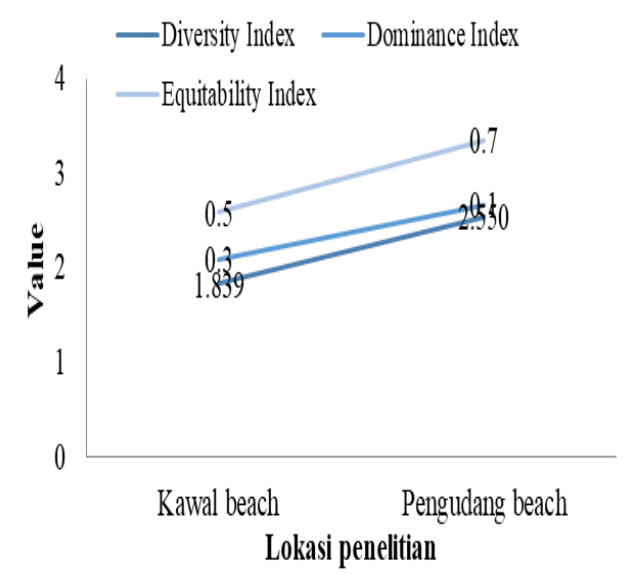

Gambar 2 Indeks Keanekaragaman, keseragaman dan dominansi di Pantai Kawal dan Pantai Pengudang

(Hookham et al., 2014) yang menyatakan bahwa nilai keanekaragaman (H') dan keseragaman (E) yang relatif rendah dipengaruhi adanya aktivitas antropogenik dari masyarakat lokal seperti penangkapan biota sebagai bahan makanan yang dikomersialnya, pembuatan cinderamata serta kondisi lingkungan yang ekstrem di zona intertidal. Sedangkan yang mempengaruhi kelimpahan dan keanekaragaman gastropoda di perairan yaitu faktor biotik dan abiotik seperti kondisi lingkungan, ketersediaan pangan, predasi oleh predator, dan persaingan (Susiana et al., 2011). Suatu komunitas dikatakan memiliki keanekaragaman spesies yang tinggi apabila komunitas tersebut terdiri dari banyak spesies dengan kelimpahan spesies yang sama atau hampir sama (Ernanto et al., 2010).

Indeks kesamaan spesies antara Pantai Kawal dan Pantai Pengudang secara keseluruhan dapat dikatakan hampir sama (Gambar 3). Hasil penelitian menunjukkan bahwa nilai kesamaan PK1PP1 sebesar 0,33; PK2-PP2 0,34, dan PK3-PP3 0,15. Hal ini diduga karena lokasi penelitian masih berada di pu- 


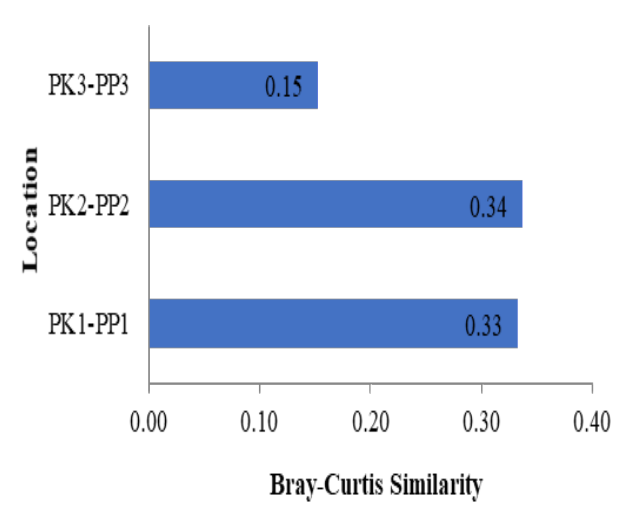

Gambar 3 Bray-Curtis Similarity

lau yang sama. Spesies pada PK3-PP3 merupakan lokasi dengan tingkat kemiripan terkuat.

\section{SIMPULAN}

Gastropoda yang ditemukan di Pantai Kawal dan Pantai Pengudang adalah 42 spesies yang termasuk dalam 15 famili dengan nilai kelimpahan $3433 \mathrm{ind} / \mathrm{m}^{2}$ untuk Pantai Kawal dan 1564 ind/ $/ \mathrm{m}^{2}$ untuk Pantai Pengudang. Berdasarkan indeks keanekaragaman (H'), keseragaman (E), dan dominansi (D) dapat dikatakan bahwa habitat gastropoda di Pantai Kawal dan Pengudang masih mendukung untuk keberlangsungan kehidupan gastropoda. Akan tetapi ada baiknya jika diatur pengelolaan dalam penangkapan biota gastropoda untuk komersil. Hal ini untuk menghindari terjadinya overfishing dan menjaga keberlanjutan sumber daya alam, mengingat perubahan iklim yang terjadi semakin cepat.

Acknowledgements : Terima Kasih kepada Kementerian Riset dan Teknologi / Badan Riset dan Inovasi Nasional karena telah memberikan kesempatan kepada penulis untuk dapat penelitian hibah dalam kategori Penelitian Dosen Pemula (PDP). Hal ini sangat membantu penulis dalam memperkaya pengalaman dalam melakukan penelitian dan penulisan karya ilmiah. Penelitian ini didanai dan didukung penuh oleh Kemen- terian Riset dan Teknologi / Badan Riset dan Inovasi Nasional.

\section{Pustaka}

Alyakrinskaya, I. (2004). Resistance to drying in aquatic mollusks. Biology Bulletin, 31(3).

Arruda, E. P. d. and Amaral, A. C. Z. (2003). Spatial distribution of mollusks in the intertidal zone of sheltered beaches in southeastern of brazil. Revista Brasileira de Zoologia, 20(2):291-300.

Crowe, T., Thompson, R., Bray, S., and Hawkins, S. (2000). Impacts of anthropogenic stress on rocky intertidal communities. Journal of Aquatic Ecosystem Stress and Recovery, 7(4):273-297.

Deepananda, K. and Macusi, E. D. (2013). Human disturbance in a tropical rocky shore reduces species diversity. The Philippine Scientist, 50:39-58.

Dolorosa, R. G. and Dangan-Galon, F. (2014). Species richness of bivalves and gastropods in iwahig riverestuary, palawan, the philippines. International Journal of Fisheries and Aquatic Studies, 2(1):207-215.

Ekau, W., Auel, H., Pörtner, H.-O., and Gilbert, D. (2010). Impacts of hypoxia on the structure and processes in pelagic communities (zooplankton, macro-invertebrates and fish). Biogeosciences, 7(5):1669-1699.

Ernanto, R., Agustriani, F., and Aryawaty, R. (2010). Struktur komunitas gastropoda pada ekosistem mangrove di muara sungai batang ogan komering ilir sumatera selatan. Maspari journal, 1(1):73-78.

Harley, C. D., Randall Hughes, A., Hultgren, K. M., Miner, B. G., Sor- 
te, C. J., Thornber, C. S., Rodriguez, L. F., Tomanek, L., and Williams, S. L. (2006). The impacts of climate change in coastal marine systems. Ecology letters, 9(2):228-241.

Hookham, B., Shau-Hwai, A. T., Dayrat, B., and Hintz, W. (2014). A baseline measure of tree and gastropod biodiversity in replanted and natural mangrove stands in malaysia: Langkawi island and sungai merbok. Tropical life sciences research, 25(1):1.

Jumawan, J. H., Tripoli, F. F., Boquia, E. E., Niez, K. L., Veronilla, J. A., Dellomes, S. A., Udtie, R. M., Seit, N. K., Hasim, N. A., and Gatinao, M. J. (2015). Species diversity and spatial structure of intertidal mollusks in padada, davao del sur, philippines. Aquaculture, Aquarium, Conservation \& Legislation, 8(3):301-309.

Kamimura, S. and Tsuchiya, M. (2004). The effect of feeding behavior of the gastropods batillaria zonalis and cerithideopsilla cingulata on their ambient environment. Marine Biology, 144(4):705-712.

Kamimura, S. and Tsuchiya, M. (2006). Effects of opportunistic feeding by the intertidal gastropods batillaria zonalis and b. flectosiphonata on material flux on a tidal flat. Marine Ecology Progress Series, 318:203-211.

Laxmana, M., Kasim, F., and Hamzah, S. N. (2020). Species diversity and similarity index of gastropod epifauna in the seagrass and mangrove ecosystems in olimoo village. The NIKe Journal, 5(2).

McQuaid, C. and Lindsay, T. L. (2000). Effect of wave exposure on growth and mortality rates of the mussel perna perna: bottom up regulation of intertidal populations. Marine Ecology Progress Series, 206:147-154.

Mills, S. W., Mullineaux, L. S., and Tyler, P. A. (2007). Habitat associations in gastropod species at east pacific rise hydrothermal vents. The Biological Bulletin, 212(3):185-194.

Moerland, M. S., Scott, C. M., and Hoeksema, B. W. (2016). Prey selection of corallivorous muricids at koh tao (gulf of thailand) four years after a major coral bleaching event. Contributions to Zoology, 85(3):291-309.

Morton, B. and Blackmore, G. (2009). Seasonal variations in the density of and corallivory by drupella rugosa and cronia margariticola (caenogastropoda: Muricidae) from the coastal waters of hong kong: plagues or aggregations. Journal of the Marine Biological Association of the United Kingdom, 89(1):147-159.

Primost, M. A., Bigatti, G., and Márquez, F. (2015). Shell shape as indicator of pollution in marine gastropods affected by imposex. Marine and Freshwater Research, 67(12):1948-1954.

Rumahlatu, D. and Leiwakabessy, F. (2017). Biodiversity of gastropoda in the coastal waters of ambon island, indonesia. Aquaculture, Aquarium, Conservation \& Legislation, 10(2):285-296.

Smith, D. (2013). Ecology of the new zealand rocky shore community, 55 pp. New Zealand Marine Studies Centre, University of Otago, Otago. Snelgrove, P. and Butman, C. (1995). Animal-sediment relationships revisited: cause versus effect. Oceanographic Literature Review, 8(42):668. 
Sorensen, A. M. (2012). Distribution, diversity, and abundance patterns of intertidal benthic molluscs on rocky shores (phuket island, thailand). The Thailand Natural History Museum Journal, 6:113-128.

Suratissa, D. M. and Rathnayake, U. (2017). Effect of pollution on diversity of marine gastropods and its role in trophic structure at nasese shore, suva, fiji islands. Journal of AsiaPacific Biodiversity, 10(2):192-198.

Susiana, S., Maritim, U., Ali, R., and Dan, D. (2011). Diversitas dan kerapatan mangrove, gastropoda dan bivalvia di estuari perancak, bali. Universitas Hasanuddin. Makassar.

Zamprogno, G. C., Fernandes, F. C., and Fernandes, L. L. (2012). Variação espaço-temporal das comunidades bentônicas do entremarés de costões rochosos no sudeste do brasil. Iheringia. Série Zoologia, 102(4):375-383.

Zhang, H., Shin, P. K., and Cheung, S. G. (2016). Physiological responses and scope for growth in a marine scavenging gastropod, nassarius festivus (powys, 1835), are affected by salinity and temperature but not by ocean acidification. ICES Journal of Marine Science, 73(3):814-824.

Kontribusi: Sirza, L.M.J: Mengambil data Lapangan; Purnama, M.F:Mengambil Data Lapangan, Analisis Data dan Menulis Hasil Penelitian dan Pembahasan; Anwar, K: Membuat Peta Penelitian; Salwiyah dan Abdullah: Mengambil Data Lapangan \& Editing. 